\title{
PERSEPSI GURU BIOLOGI TERHADAP KOMPETENSI PEDAGOGIK MAHASISWA CALON GURU BIOLOGI DI KABUPATEN SIKKA
}

\author{
Maria Efrasia Manang, Yohanes Nong Bunga ${ }^{*}$ \\ Prodi Pendidikan Biologi, Universitas Nusa Nipa, Jl. Kesehatan No. 3 Alok Timur \\ Maumere, Indonesia \\ ${ }^{*}$ Email: Uma.Sandy910@gmail.com
}

Doi: https://doi.org/10.31943/mangiferaeduv4i2.53

Received: 04 Desember 2019 Accepted: 29 Januari 2020 Published: 31 Januari 2020 Citasi: Manang, M, E,. Bunga, Y, N. 2020. Persepsi Guru Biologi Terhadap Kompetensi Pedagogik Mahasiswa Calon Guru Biologi di Kabupaten Sikka. Jurnal Mangifera Edu, 4(2), 143-156.

\begin{abstract}
Teacher competency is assumed to still be one of the factors that can determine student learning success. This problem needs to be explored further so that the cause can be known with certainty. This research aims to analyse the perception of biological teachers on pedagogic competence of prospective biological teachers in Sikka district. Pedagogic competence is one of the important components that also determine the success of the learning process in school. Prospective teachers need to equip these competencies so that they can apply them in the workforce. The perception of biological teachers on pedagogic competence of prospective biological teachers has a role in determining the progress of the learning process. In conducting this research, the researcher uses descriptive qualitative approach. Data sources come from biology teachers in 6 senior high schools (1 SMA Negeri and 5 SMA Swasta) in district Sikka. In wich the subject of this research is using purposive sampling technique. The data collected through interviews, questionare and document study. The validity of the data is determined using the credibility, transferability, dependability, and confirmability. Data analysis technique used refers to the concept of data reduction, data display, and conclusions or verifications. The results showed that the perception of biological teachers on pedagogic competence of prospective biological teachers in Sikka district belongs to acceptable category, although for the dimension of learning process that can inspire students learning motivation still have problem that need to be improved.
\end{abstract}

Keywords: Conten Knowledge (CK), Competence Pedagogic, Student Prospective Teachers

\begin{abstract}
ABSTRAK
Kompetensi guru diasumsikan masih menjadi salah satu faktor yang dapat menentukan keberhasilan proses pembelajaran di sekolah. Masalah ini perlu ditelusuri sehingga penyebabnya dapat diketahui secara pasti. Penelitian ini bertujuan untuk menganalisis persepsi guru biologi terhadap kompetensi pedagogik mahasiswa calon guru biologi di Kabupaten Sikka. Penelitian ini menggunakan metode kualitatif dengan pendekatan deskriptif. Subjek penelitian ditentukan menggunakan teknik purposive
\end{abstract}


sampling. Sumber data berasal dari guru biologi di 6 Sekolah Menengah Atas (1 SMA Negeri dan 5 SMA Swasta) di Kabupaten Sikka. Data dikumpulkan melalui wawancara, pengisian angket dan studi dokumen. Keabsahan data ditentukan dengan menggunakan kriteria derajat kepercayaan, keteralihan, kebergantungan, dan kepastian. Teknik analisis data yang digunakan ialah reduksi data, penyajian data, dan penarikan kesimpulan/verifikasi. Hasil penelitian menunjukkan bahwa persepsi guru biologi terhadap kompetensi pedagogik mahasiswa calon guru biologi di Kabupaten Sikka termasuk dalam kategori baik, meski pada dimensi proses pembelajaran yang dapat membangkitkan semangat belajar siswa masih mengalami kendala yang perlu dibenahi.

Kata Kunci: Conten Knowledge (CK), Kompetensi Pedagogik, Mahasiswa Calon Guru

\section{PENDAHULUAN}

Kompetensi mempunyai arti penting dalam menjalani suatu profesi. Kompetensi yang dimiliki dapat menjadi alat bantu untuk bertahan hidup ditengah ketatnya persaingan hidup. Tidak dapat dipungkiri bahwa kompetensi juga harus dimiliki serta dikembangkan oleh mahasiswa calon guru biologi. Kompentensi merupakan modal untuk mendidik para generasi penerus bangsa menjadi manusia yang berkualitas. Astuty (2015: 167) menyatakan bahwa kompetensi pendidik memberi pengaruh yang signifikan terhadap hasil belajar siswa.

Data hasil observasi tahun 2018 di kampus Universitas Nusa Nipa menunjukkan bahwa beberapa mahasiswa harus mengikuti program remidial matakuliah microteaching untuk dapat mengikuti program pengalaman lapangan (PPL). Kondisi ini menginformasikan bahwa mahasiswa calon guru belum sepenuhnya siap untuk melakukan praktik yang dapat meningkatkan kompetensi pedagogiknya. Beberapa penelitian menunjukkan kompetensi guru masih menjadi masalah dalam peningkatan kualitas hasil belajar siswa (Leksono et al., 2013: 417; Leonard, 2015: 200; Bunga et al., 2016: 161). Masalah ini perlu ditelusuri lebih jauh sehingga menyebabnya dapat diketahui secara pasti.

Kompetensi pedagogik merupakan salah satu aspek kompetensi yang harus dimiliki oleh guru. Guru dituntut untuk dapat memahami siswa, memahami bagaimana memberikan pengajaran yang benar pada siswa melalui prinsip-prinsip pembelajaran yang mendidik dan mengidentifikasikan bekal ajar awal siswa. Kompetensi ini tidak diperoleh secara tiba-tiba, tetapi melalui upaya pelatihan serta belajar secara terus-menerus dan sistematis (Sukaesih et al., 2017: 73). Berbekal kompetensi pedagogik guru dapat membimbing siswa menuju suatu tujuan sehingga kelak siswa secara mandiri mampu menyelesaikan tugas hidupnya. 
Penelitian terkait kompetensi guru telah dilakukan, Oetpah (2019: 37) dari penelitiannya dihasilkan bahwa kompetensi pedagogik dan kompetensi profesional $70 \%$ dapat mempengaruhi prestasi siswa dalam pembelajaran biologi. Sejalan pula dengan Gaol \& Aziz (2013: 67) menyatakan bahwa kompetensi kepribadian dan kompetensi sosial sangat penting dalam meningkatkan prestasi peserta didik. Purwoko (2017: 56) menyatakan bahwa Conten Knowledge (CK) harus dimiliki oleh guru dan calon guru. Bagi mahasiswa calon guru, CK merupakan hal yang sangat penting sebagai penguasaan salah satu tuntutan dari standar kompetensi. Pengetahuan ini berisi bagaimana calon guru mampu melakukan organisasi konten materi. Penelitian Susanti et al. (2013: 46) menyatakan kompetensi merupakan bagian yang tidak terpisakan dari guru dalam melaksanakan profesinya. Kompetensi pedagogik adalah modal dasar guru dalam membina dan mendidik siswa sehingga tercapai mutu pendidikan yang lebih baik. Keterbatasan kompetensi yang dimiliki oleh guru atau calon guru dapat menyebabkan permasalahan dalam proses interaksi dan pembelajaran. Pembelajaran Biologi dan komunitas belajar tercapai dengan baik, yaitu disarankan guru atau calon guru dapat mengubah pengajaranya kearah yang lebih beorientasi pada kompetensi (Elster, 2008).

Peraturan Pemerintah Republik Indonesia Nomor 74 Tahun 2008 menyebutkan secara akademis guru dikatakan telah berkompeten dalam bidangnya apabila telah memenuhi kualifikasi akademik sesuai dengan jenis, jenjang, dan satuan pendidikan formal. Aturan ini baiknya dijadikan rambu-rambu bagi mahasiswa calon guru biologi dalam mengasah kemampuannya di lembaga pendidikan tinggi. Oleh karena itu fase persiapan dan pengasahan kompetensi menjadi penting untuk dilaksanakan. Pada sisi lainnya, penerimaan formasi guru calon pegawai negeri sipil perlu memenuhi passing grade yang sangat menantang (Pos-Kupang.com). Diskusi ini menjadi lebih menarik ketika hasil persiapan mahasiswa calon guru biologi pada lembaga pendidikan tinggi, sehingga tujuan penelitian ini berkaitan dengan kompetensi pedagogik ditelusuri dari sudut pandang guru biologi tempat mahasiswa melaksanakan PPL.

\section{METODOLOGI PENELITIAN}

Penelitian yang dilaksanakan adalah penelitian kualitatif. Dalam penelitian ini, peneliti mewawancarai lima orang guru biologi dan lima orang kepala sekolah dari lima sekolah menengah atas yang berbeda di wilayah Kabupaten Sikka. Kelima orang guru biologi tersebut juga diminta untuk mengisi angket yang diberikan. Wawancara dilaksanakan di lingkungan sekolah pada jam kerja sesuai dengan waktu luang yang 
dimiliki subjek penelitian. Pengisian angket dilaksanakan guru di sekolah pada jam istirahat. Selain itu peneliti juga melakukan studi dokumentasi untuk menjawab tujuan penelitian.

Instrumen angket dan instrumen wawancara yang disusun oleh peneliti merupakan penurunan dimensi-dimensi dalam kompetensi pedagogik. Dimensi-dimensi tersebut adalah a) penguasaan karakteristik belajar siswa, b) menyesuaikan metode pembelajaran sesuai dengan karakteristik siswa, c) merancang rencana pembelajaran sesuai dengan silabus, d) kemampuan mahasiswa calon guru biologi melaksanakan aktivitas pembelajaran sesuai dengan RPP, e) membangkitkan semangat belajar siswa, f) menggunakan bahasa yang baku dan santun dalam menyampaikan materi pelajaran, dan $\mathrm{g}$ ) melakukan evaluasi hasil belajar (Kurniasih \& Sani, 2017: 45-51). Dokumentasi yang dikaji oleh peneliti berupa dokumen laporan mahasiswa PPL yang ada di sekolah, laporan kepala sekolah, nilai mahasiswa PPL, nilai siswa dan video. Dokumen-dokumen tersebut diperoleh dari subjek penelitian.

Penelitian kualitatif ini peneliti melakukan teknik keabsahan data yakni, kriteria derajat kepercayaan (credibility), keteralihan (transferability), kebergantungan (dependability), dan kepastian (confirmability) (Moleong, 2012: 324). Teknik analisis data yang digunakan mengacu pada konsep Milles \& Huberman (2014: 107) terdiri dari tiga tahap yaitu, reduksi data (data reduction), penyajian data (display data), dan penarikan kesimpulan/verifikasi (conclusion drawing/verification).

\section{HASIL DAN PEMBAHASAN}

Kompetensi pedagogik merupakan kemampuan seorang guru dalam proses pembelajaran yang berhubungan dengan peserta didik. Informasi mengenai kompetensi pedagogik mahasiswa calon guru biologi diperoleh melalui wawancara, pengisian angket, dan studi dokumentasi. Wawancara dilakukan dengan informan pada jam istirahat sehingga tidak mengganggu aktivitas pembelajaran. Kompetensi pedagogik mahasiswa calon guru biologi dapat dilihat pada Tabel 1 berikut. 
Tabel 1. Interpretasi Kompetensi Pedagogik Mahasiswa Calon Guru Biologi

No $\begin{gathered}\text { Sumber } \\ \text { Data }\end{gathered}$ Dimensi Interpretasi

1. Wawancara a.Penguasaan Mahasiswa calon guru biologi biologi dapat karakteristik menguasai karakteristik belajar siswa dikelas. belajar siswa Mahasiswa calon guru selalu belajar dan berusaha untuk dapat memahami karakteristik belajar siswa dikelas, sehingga pada akhirnya mahasiswa calon guru mampuh memahami karakteristik belajar siswa walaupun belum sempurna tetapi sudah dalam kategori baik.

\begin{tabular}{|c|c|}
\hline $\begin{array}{l}\text { b.menyesuaikan } \\
\text { metode } \\
\text { pembelajaran }\end{array}$ & $\begin{array}{l}\text { Mahasiswa calon guru biologi dapat } \\
\text { menyesuaikan metode pembelajaran yang } \\
\text { sesuai dengan karakteristik siswa. }\end{array}$ \\
\hline $\begin{array}{l}\text { sesuai dengan } \\
\text { karakteristik siswa }\end{array}$ & $\begin{array}{l}\text { Mahasiswa calon guru biologi sudah mampu } \\
\text { memilih metode pembelajaran yang dapat } \\
\text { mengaktifkan siswa pada saat pembelajaran } \\
\text { berlangsung. }\end{array}$ \\
\hline $\begin{array}{l}\text { c. merancang rencana } \\
\text { pembelajaran } \\
\text { sesuai dengan }\end{array}$ & $\begin{array}{l}\text { Guru pamong selalu mengarahkan atau } \\
\text { mengajarkan mahasiswa calon guru dalam } \\
\text { menyusun atau membuat rencana } \\
\text { pembelajaran sesuai dengan silabus. }\end{array}$ \\
\hline & $\begin{array}{l}\text { Mahasiswa calon guru merancang rencana } \\
\text { pembelajaran sesuai dengan silabus. }\end{array}$ \\
\hline $\begin{array}{l}\text { d.kemampuan } \\
\text { mahasiswa calon } \\
\text { guru biologi } \\
\text { melaksanakan } \\
\text { aktivitas } \\
\text { pembelajaran } \\
\text { sesuai dengan RPP }\end{array}$ & $\begin{array}{l}\text { Mahasiswa calon guru melaksanakan aktivitas } \\
\text { pembelajaran sesuai dengan rancangan yang } \\
\text { telah disusun. }\end{array}$ \\
\hline $\begin{array}{l}\text { e.membangkitkan } \\
\text { semangat belajar } \\
\text { siswa }\end{array}$ & $\begin{array}{l}\text { Pelaksanaan aktivitas belajar yang dilakukan } \\
\text { oleh mahasiswa calon guru belum bisa } \\
\text { membangkitkan semangat belajar siswa. } \\
\text { Mahasiswa calon guru biologi belum } \\
\text { menguasai materi pembelajaran dengan baik } \\
\text { sehingga pada saat mengajar mahasiswa calon } \\
\text { guru selalu membuku. }\end{array}$ \\
\hline & $\begin{array}{l}\text { Masih lemah dalam mengelola kelas, } \\
\text { pembelajaran masih monoton/ pembelajaran } \\
\text { kurang bervariasi, masih ragu-ragu dalam } \\
\text { menjelaskan materi dan belum bisa } \\
\text { memberikan pertanyaan yang mendorong } \\
\text { interaksi antar siswa dalam pembelajaran. }\end{array}$ \\
\hline $\begin{array}{l}\text { f. menggunakan } \\
\text { bahasa yang baku } \\
\text { dan santun dalam } \\
\text { menyampaikan }\end{array}$ & $\begin{array}{l}\text { Mahasiswa calon guru biologi dalam proses } \\
\text { kegiatan pembelajaran selalu menggunakan } \\
\text { bahasa yang baku dan santun. }\end{array}$ \\
\hline
\end{tabular}


Jurnal Mangifera Edu, Volume 4, Nomor 2, Januari 2020, Halaman 143-156

\begin{tabular}{|c|c|c|c|}
\hline No & $\begin{array}{c}\text { Sumber } \\
\text { Data }\end{array}$ & Dimensi & Interpretasi \\
\hline & & \multicolumn{2}{|l|}{ materi pelajaran } \\
\hline & & $\begin{array}{l}\text { g. melakukan evaluasi } \\
\text { hasil belajar }\end{array}$ & $\begin{array}{l}\text { Kegiatan evaluasi pada setiap akhir pelajaran } \\
\text { merupakan suatu keharusan bagi seorang guru. } \\
\text { Kegiatan evaluasi merupakan alat untuk } \\
\text { mengecak sejaumana pemahaman siswa } \\
\text { terhadap materi yang sudah dijelaskan. }\end{array}$ \\
\hline & & & $\begin{array}{l}\text { Mahasiswa calon guru selalu melaksanakan } \\
\text { kegiatan evaluasi setiap akhir pelajaran. }\end{array}$ \\
\hline 2. & Angket & Nomor a-g & $\begin{array}{l}\text { Secara umum guru bologi menyatakan bahwa } \\
\text { kompetensi pedagogik mahasiswa calon guru } \\
\text { biologi tergolong baik. }\end{array}$ \\
\hline 3. & $\begin{array}{l}\text { Studi } \\
\text { Dokumen }\end{array}$ & Nomor a-g & $\begin{array}{l}\text { Kompetensi pedagogik mahasiswa calon guru } \\
\text { diperoleh dari keterlibatan mahasiswa calon } \\
\text { guru biologi dalam menyusun RPP, LKS dan } \\
\text { materi permbelajaran yang terlampir dalam } \\
\text { laporan PPL mahasiswa calon guru biologi. }\end{array}$ \\
\hline
\end{tabular}

Penelitian tentang persepsi guru biologi terhadap kompetensi pedagogik mahasiswa calon guru biologi ditinjau dari lima dimensi yaitu,

a) Pengusaan Karakteristik Belajar Siswa.

Informasi mengenai kompetensi pedagogik mahasiswa calon guru biologi dalam memahami karakteristik belajar siswa diperoleh melalui wawancara dengan AL di ruangan guru. Hasil wawancara disajikan sebagai berikut.

"Iya, mahasiswa calon guru biologi sudah bisa menguasai karakteristik belajar siswa dikelas walaupun belum semuanya tetapi sudah baik. Awalnya mereka merasa kesulitan dalam memahami karakter peserta didik tetapi setelah mereka belajar dan berusaha akhirnya mereka dapat menguasai karakter belajar siswa" (Waw. 30/9/2019).

Data hasil wawancara menunjukkan bahwa mahasiswa calon guru biologi dapat menguasai karakteristik belajar siswa di kelas. Pernyataan lain diungkapkan oleh guru biologi yaitu masih terdapat mahasiswa calon guru yang tidak begitu memahami karakter siswa. Mahasiswa calon guru hanya mengenal beberapa siswa dengan karakter yang menonjol saja, seperti siswa yang menjabat sebagai ketua kelas, siswa yang pintar, aktif dan siswa yang sangat nakal.

Tujuan guru mengenal dan memahami karakteristik siswa adalah agar guru dapat membantu pertumbuhan dan berkembangannya secara efektif, menentukan materi yang akan diberikan, menggunakan prosedur mengajar yang tepat, dan mengadakan diagnosis atas kesulitan belajar yang dialami oleh siswa (Fanani, 2016: 223). Sejalan pula 
Purwandari (2017: 204) menyatakan bahwa guru harus memahami hal terpenting seperti memahami dunia anak, karakteristik anak, dan proses pendidikan anak. Berdasarkan hasil pengolahan data wawancara dan angket dapat diketahui bahwa persepsi guru biologi terhadap kemampuan mahasiswa calon guru dalam menguasai karakteristik belajar peserta didik termasuk dalam kategori baik.

b) Menyesuaikan Metode Pembelajaran Sesuai Dengan Karakteristik Siswa

Informasi mengenai kemampuan mahasiswa calon guru biologi dalam menyesuaikan metode pembelajaran sesuai dengan karakteristik belajar siswa diperoleh dari hasil wawancara dengan FSS. Hasil wawancara disajikan sebagai berikut.

"Umumnya mahasiswa calon guru biologi sudah dapat menyesuaikan metode pembelajaran sesuai dengan karakter belajar peserta didik. Mahasiswa calon guru sudah baik dalam memilih metode pembelajaran, tetapi dalam menyampaikan materinya belum terlalu baik masih raguragu" (Waw. 22/7/2019).

Data hasil wawancara menunjukkan bahwa umumnya mahasiswa calon guru biologi sudah baik kemampuannya dalam memilih metode pembelajaran yang sesuai dengan karakteristik siswa, hanya kemampuan dalam menyampaikan materi yang sesuai dengan metode pembelajaran masih perlu ditingkatkan. Hal senada diungkap oleh AY pada tanggal 5 Agustus 2019, yang mengatakan bahwa mahasiswa calon guru biologi sudah dapat menyesuaikan metode pembelajaran sesuai dengan karakteristik belajar peserta didik, tetapi dalam menyampaikan materi pembelajaran perlu ditingkatkan lagi. Mahasiswa calon guru biologi sudah pandai dalam memilih metode pembelajaran sehingga dalam proses belajar mengajar siswa terlihat sangat aktif. Guru yang efektif dalam menggunakan metode pembelajaran dapat meningkatkan minat siswa dalam proses belajar mengajar sehingga siswa dapat lebih cepat dan mudah memahami materi pembelajaran.

Peningkatan prestasi belajar siswa dapat dilakukan dengan adanya penggunaan metode pembelajaran yang baik, guru hendaknya mampu untuk merencanakan kegiatan belajar yang baik dengan memilih metode pembelajaran yang sesuai dengan materi dan karakter siswa (Nasution, 2017: 14). Penggunaan metode pembelajaran yang tepat dan sesuai dengan kebutuhan siswa di sekolah dalam proses pembelajaran dapat memberikan kemampuan pemahaman siswa terhadap konsep-konsep biologi. Hasil penelitian menunjukkan bahwa, persepsi guru biologi terhadap kemampuan mahasiswa calon guru biologi dalam menyesuaikan metode pembelajaran dengan karakter siswa tergolong baik.

c) Merancang Rencana Pembelajaran Sesuai dengan Silabus 
Informasi mengenai kemampuan mahasiswa calon guru biologi merancang rencana pembelajaran sesuai dengan silabus diperoleh dari hasil wawancara dengan MFK. Hasil wawancara disajikan sebagai berikut.

"Iya, sebelum melaksanakan kegiatan KBM calon guru terlebih dahulu menyusun rencana pembelajaran. Mahasiswa calon guru menyusun rencana pembelajaran sesuai dengan silabus." (Waw. 23/7/2019)

Data hasil wawancara menunjukkan bahwa pada saat mahasiswa calon guru biologi melaksanakan proses pembelajaran, mahasiswa terlebih dahulu menyiapkan atau membuat Rencana Pelaksanaan Pembelajaran (RPP) yang sesuai dengan silabus. Hal senada juga dapat diperoleh dari studi dokumentasi dan data angket yang menunjukkan bahwa mahasiswa calon guru membuat RPP sesuai dengan silabus seperti yang terlampir dalam laporan PPL mahasiswa calon guru biologi.

Perancangan pembelajaran merupakan salah satu kompetensi pedagogik guru yang tertuju pada pelaksanaan pembelajaran. Perancang pembelajaran sedikitnya mencakup tiga kegiatan yaitu, (1) identifikasi kebutuhan (2) identifikasi kompetensi (3) penyusun program pembelajaran. Perancangan pembelajaran merupakan langkah yang sangat penting sebelum pelaksanaan pembelajaran. Perencanaan pembelajaran dituangkan ke dalam RPP atau desain pembelajaran. RPP memuat Kompetensi Inti (KI), Kompetensi Dasar (KD), dan indikator yang harus dicapai sesuai dengan silabus (Susetya, 2016: 138).

Mahasiswa calon guru biologi mampu merencanakan pengelolaan pembelajaran seperti merumuskan tujuan pembelajaran sesuai dengan kompetensi dasar yang terdapat dalam silabus. Hasil wawancara dan angket menunjukkan bahwa kemampuan mahasiswa calon guru dalam merancang rencana pembelajaran sesuai dengan silabus dinilai sangat baik.

d) Kemampuan Mahasiswa Calon Guru Biologi Melaksanakan Aktivitas Pembelajaran Sesuai dengan RPP.

Informasi mengenai kemampuan mahasiswa calon guru biologi dalam melaksanakan aktivitas pembelajaran sesuai dengan rencana pembelajaran diperoleh dari wawancara yang disajikan sebagai berikut.

"Walaupun belum semuanya bisa tetapi sebagian besar mahasiswa calon guru biologi dapat melaksanakan aktivitas pembelajaran sesuai dengan rencana pelaksanaan pembelajaran (RPP)." (Waw 20/7/2019).

Hasil wawancara menunjukkan bahwa sebagian besar mahasiswa calon guru biologi dapat melaksanakan aktivitas pembelajaran sesuai dengan RPP yang telah disusun. Hal 
senada juga diungkapkan oleh AY pada tanggal 5 Agustus 2019 yang menyatakan bahwa sebagian besar mahasiswa calon guru biologi mampu melaksanakan proses pembelajaran sesuai dengan RPP yang telah disusun. Meskipun demikian mahasiswa calon guru masih perlu meningkatkan kemampuan membagi waktu.

Kemampuan melaksanakan pembelajaran merupakan kemampuan dalam menerapkan keterampilan mengajar, seperti membuka pelajaran, bertanya, memberikan penguatan, dan menutup pelajaran (Akbar \& Anggraeni, 2018: 62). Sejalan dengan Ozcan (2003) pada penelitiannya yang dilakukan di sekolah tinggi dan sekolah menegah di Turki mengatakan bahwa kompetensi guru, kurikulum, dan alokasi waktu mempengaruhi dalam pembelajaran biologi dan hasil belajar siswa. Mahasiswa calon guru biologi sudah mampu melaksanakan proses pembelajaran sesuai dengan langkah-langkah yang disusun dalam RPP, meskipun masih ada hal-hal tertentu yang perlu ditingkatkan lagi. Hasil data wawancara dan data angket persepsi guru biologi terhadap kemampuan mahasiswa calon guru biologi dalam melaksanakan proses pembelajaran sesuai dengan RPP dinilai baik.

e) Membangkitkan Semangat Belajar Siswa.

Informasi mengenai kemampuan mahasiswa calon guru biologi dalam mendorong semangat belajar siswa diperoleh dari wawancara dengan MFK yang bertempat diruang guru. Hasil wawancara disajikan sebagai berikut.

"Mahasiswa calon guru biologi belum bisa melaksanakan aktivitas pembelajaran yang dapat mendorong semangat belajar peserta didik. Mahasiswa calon guru biologi sudah menggunakan metode pembelajaran yang baik, tetapi belum sepenuhnya menguasai materi pembelajaran sehingga pada saat mengajar selalu membuku, mahasiswa calon guru biologi juga belum bisa mengelolah kelas dengan baik."(Waw. 23/7/2019).

Hasil wawancara menunjukkan bahwa, aktivitas pembelajaran yang dilakukan oleh mahasiswa calon guru biologi belum bisa membangkitkan semangat belajar siswa. Mahasiswa calon guru biologi belum menguasai materi pembelajaran sehingga pada saat mengajar selalu melihat buku. Cara mengajar seperti ini memberikan kesan sangat monoton dimana hanya mambaca dan menjelaskan tentang materi pelajaran saja.

Wawancara terhadap MP pada tanggal 20 Juli 2019 dilakukan diruang guru biologi. Hasil wawancara menyatakan bahwa akivitas pembelajaran yang dilakukan oleh mahasiswa calon guru belum bisa membagkitkan semangat belajar siswa. Cara mengajar mahasiswa calon guru masih belum bervariasi, calon guru terlihat banyak membuka buku di kelas sehingga siswa merasa jenuh dan bosan. Siswa dapat termotivasi untuk belajar 
manakala siswa memiliki minat untuk belajar. Upaya yang dilakukan untuk dapat mendorong semangat belajar siswa diantaranya adalah guru bisa menghubungkan bahan pelajaran yang akan diajarkan dengan kebutuhan siswa. Mahasiswa calon guru biologi dapat menggunakan berbagai model dan strategi pembelajaran secara bervariasi serta menciptakan suasana yang menyenangkan dalam belajar sehingga siswa tidak jenuh dan bosan.

Auerbach \& Andrews (2018), bahwa salah satu kompetensi yang sebaiknya dimiliki oleh guru sebagai startegi dan perilaku mengajar yaitu manajemen pengelolaan kelas, membangkitkan semangat belajar siwa aktif membutuhkan pelatihan pada seorang guru. Lisdiana et al. (2017: 225) menyatakan bahwa, guru yang kompeten mampu menciptakan lingkungan belajar yang efektif, menyenangkan, dan mampu mengelola kelasnya. Berdasarkan hasil wawancara dan data angket menyatakan bahwa kemampuan mahasiswa calon guru biologi dalam membangkitkan semangat belajar peserta didik tergolong cukup baik. Oleh karena itu pelatihan merupakan upaya efektif untuk dapat mengatasi dan meningkatkan kemampuan ini.

f) Menggunakan Bahasa yang Baku dan Santun dalam Menyampaikan Materi Pembelajaran

Informasi mengenai kemampuan mahasiswa calon guru biologi dalam menyampaikan materi pembelajaran menggunakan bahasa yang baku dan santun diperoleh dari hasil wawancara dengan FB. Hasil wawancara disajikan sebagai berikut.

"Iya, dalam menyampaikan materi pembelajaran mahasiswa calon guru biologi selalu menggunakan bahasa yang baku dan santun, bahasa yang bisa dimengerti oleh peserta didik."(waw. 27/7/2019).

Hasil wawancara menunjukkan bahwa mahasiswa calon guru biologi selalu menggunakan Bahasa Indonesia yang baku dan santun dalam menyampaikan materi pembelajaran kepada siswa di kelas. Mahasiswa calon guru biologi juga selalu menggunakan bahasa yang mudah dimengerti oleh siswa. Ragam bahasa yang baku dan santun merupakan ragam bahasa yang paling sering digunakan oleh guru dalam proses pembelajaran di kelas sehingga dapat menciptakan komunikasi yang baik dan menciptakan proses pembelajaran yang baik pula. Penggunaan bahasa yang baku dan santun turut membantu penerimaan siswa terhadap pesan yang disampaikan serta mampu membangun relasi sosial yang baik antara mahasiswa calon guru biologi dan siswa.

Nartani \& Rahmawati (2018: 391) menyatakan, keterampilan berbahasa harus dimiliki oleh seorang guru kerena guru merupakan pembimbing dan fasilitator. 
Kerterampilan berbahasa yang dimiliki membantu guru dalam menyampaikan materi pembelajaran. Hal ini berarti pelaksanaan pembelajaran harus berangkat dari proses dialogis dalam proses pembelajaran sehingga melahirkan pemikiran kritis dan komunikatif. Komunikasi merupakan hal penting untuk mencapai pendidikan sejati. Hasil wawancara dan angket menunjukkan bahwa kemampuan mahasiswa calon guru biologi dalam menggunakan bahasa yang baku dan santun tergolong sangat baik. Sejalan dengan hasil penelitian Potyrala, et all (2011), yang menyatakan sekarang ini sangat berkembanga media sosial yang terkait dengan komunikasi atau e-komunikasi sebagai stimlator pendidikan yang berkaitan dengan psikologi siswa membutuhkan guru menggunakan strategi yang mengarah struktur pengetahuan siswa, dalam menanggapi informasi baru memungkinkan prioritas elaborasi untuk pelatihan guru biologi.

g) Evaluasi Hasil Belajar.

Informasi mengenai kemampuan mahasiswa calon guru biologi dalam melaksanakan evaluasi diakhir pembelajaran dapat diperoleh dari hasil wawancara dengan MP. Wawancara dilaksanakan di ruang guru biologi. Hasil wawancara disajikan sebagai berikut.

"Iya, selama saya membimbing mahasiswa calon guru biologi, saya selalu mengarahkan mereka untuk selalu melaksanakan evaluasai pada setiap akhir pelajaran.” (Waw. 20/7/2019)

Hasil wawancara menunjukkan bahwa mahasiswa calon guru biologi selalu melaksanakan kegiatan evaluasi pada setiap akhir pelajaran. Kegiatan evaluasi pada setiap akhir pelajaran merupakan suatu keharusan bagi seorang guru. Evaluasi merupakan kegiatan untuk melihat pemahaman siswa terhadap materi yang sudah dijelaskan. Evaluasi dilakukan dengan tes berupa soal. Wawancara selanjutnya dilakukan dengan AL pada tanggal 30 Juli 2019 wawancara dilaksanakan di ruang guru. Hasil wawancara menginformasikan bahwa mahasiswa calon guru biologi selalu melakukan evaluasi pada setiap akhir pembelajaran. Hal ini juga dapat diketahui dari data studi dokumentasi berupa laporan PPL mahasiswa calon guru. Mahasiswa calon guru menyusun soal yang digunakan sebagai alat evaluasi, soal disusun sesuai dengan tingkat kemampuan siswa.

Kompetensi pedagogik juga menuntut seorang guru agar mampu dalam menyusun alat penilaian atau evaluasi. Alat evaluasi yang di siapkan hendaknya mengandung unsur dialogis artinya dapat dijadikan bahan untuk mengetahui kelemahan siswa belajar dan guru mengajar. Hasil penelitian Hasse, et all (2014) bahwa guru biologi masa depan sebaiknya memiliki kemampuan menganalisis pembelajaran eksperimen dan penilain yang terfokus 
pada hasil eksperimen siswa. Didukung pula oleh Martini (2017) yaitu pembelajaran IPA menuntut seorang guru menguasai penilaiannya tidak tergantung pada bentuk asesmen yang menggunakan paper and pencil test atau bentuk tes objektif. Bentuk asesmen yang digunakan disebut authentic assessment atau altenative assessment, seperti portfolio, observasi proses, dinamika kelompok, studi kasus, simulasi dan permainan, performance appraisal.

Kenyataan di lapangan menunjukkan bahwa guru biologi memandang para mahasiswa calon guru biologi memiliki kemampuan yang baik dalam melakukan kegiatan evaluasi sampai pada pembuatan soal.

\section{SIMPULAN}

Berdasarkan hasil dan pembahasan dapat disimpulkan bahwa dimensi a) pengusaan karakteristik belajar peserta didik, b) menyesuaikan metode pembelajaran sesuai dengan karakteristik siswa, c) merancang rencana pembelajaran sesuai dengan silabus, d) kemampuan mahasiswa calon guru biologi melaksanakan aktivitas pembelajaran sesuai dengan RPP, dan e) membangkitkan semangat belajar peserta didik, termasuk dalam kategori cukup baik. Dimensi f) menggunakan bahasa yang baku dan santun dalam menyampaikan materi pelajaran, termasuk dalam kategori sangat baik, g) melakukan evaluasi hasil belajar termasuk dalam kategori baik. Hasil penelitian ini dapat dijadikan sebagai dasar acuan peningkatan kompetensi pedagogik mahasiswa calon guru biologi pada waktu mendatang dan sebagai informasi awal untuk penelitian lanjutan.

\section{DAFTAR PUSTAKA}

Akbar, A. \& Anggraeni, P. (2018). Kesesuaian rencana Pelaksanaan pembelajaran dan proses pembelajaran. Jurnal Pesona Dasar, 6(2), 55-65.

Astuty, E. (2015). Implementation Analysis of Lecturer's Pedagogical Competence on Students's Academic Achievement. Journal of Management Research, 7(2), 152168

Auerbach, A.J.J. dan Andrews T.C. (2018). Pedagogical knowledge for active-learning instruction in large undergraduate biology courses: a large-scale qualitative investigation of instructor thinking. International Journal of Stem Education, 5(1), 19.

Bunga, Y. N., Prasetyo, A. P. B., \& Susanti, R. (2016). Profesionalitas Guru Dalam Pembelajaran Biologi: Studi Kasus Sekolah Menengah Atas Swasta Katolik Bhaktyarsa Maumere. Journal of Innovative Science Education, 5(2), 152-162. 
Elster, D. (2008). Biology in Context: teachers' professional development in learning communities. JBE, 43(1).

Fanani, M. Z. (2016). Persepsi Guru Pamong Terhadap Pelaksanaan Praktik Pengalaman Lapangan (PPL) Mahasiswa. Jurnal Realita, 14(2), 220-233.

Gaol, M. L. \& Aziz, A. Perbedaan kompetensi kepribadian dan kompetensi sosial guru SD NegJeri yang suda sertifikasi dan yang belum sertifikasi. Jurnal Analitika, 5(2), 6269.

Potyrala. K, et all. (2011). New Competence Of Biology Teacher In The Face Of Social And Cultural Changes. Western Anatolia Journal of Educational Sciences (WAJES).Dokuz Eylul University Institute: Turkey.

Kurniasih, I. \& Sani, B. (2017). Kompetensi pedagogik. Bandung: Kata Pena.

Leksono, S. M., Rustaman, N., \& Redjeki, S. (2013). Kemampuan Profesional Guru Biologi Dalam Memahami dan Merancang Model Pembelajaran Konservasi Biodiversitas di SMA. Cakrawala Pendidikan. 32(3): 408-419.

Leonard. 2015. Kompetensi Tenaga Pendidik Di Indonesia, Analisis Dampak Rendahnya Kualitas SDM Guru dan Solusi Perbaikannya. Jurnal Formatif, 5(3), 192-201.

Lisdiana, Widyastuti, N., Widiyaningrum, P. (2017). Analisis Kompetensi Guru Biologi Berdasarkan Persepsi Siswa SMA Di Kota Semarang. Jurnal of Inovative Science Education, 6(2), 212-226.

Miles, M. B., \& Huberman, A. M. (2014). Analisis Data Kualitatif. Terjemahan: Tjetjep Rohendi Rohidi. Jakarta: Universitas Indonesia Press

Moleong, J. L. (2012). Metodologi Penelitian Kualitatif. Bandung: Remaja Rosda Karya

Nartani, C. I. \& Rahmawati, A. (2018). Kompetensi Sosial Guru Dalam Berkomunikasi Secara Efektif Dengan Siswa Melalui Kegiatan Pembelajaran Bahasa Indonesia Di SD Negeri Rejowinangun 3 Kota Gede Yokyakarta. Jurnal Pendidikan ke-SD-an, 4(3), 388-392.

Nasution, M. K. (2017). Penggunaan Metode Pembelajaran Dalam Peningkatan Hasil Belajar Siswa. Studia Didaktika, 11(1), 9-18.

Oetpah, F. (2019). Kompetensi Pedagogik dan Kompetensi Profesionl Guru: Kontribusi Terhadap Peningkatan Hasil Belajar. Jurnal Mangifera Edu, 4(1). 71-38

Ozcan, N. (2003). A Group Of Students' And Teachers' Perceptions With Respect To Biology Education At High School Level. A Thesis The Department Of Secondary Science And Mathematics Education: Turkey.

PP. (2008). Peraturan Pemerintah Republik Indonesia No. 74 Tahun 2008 tentang Guru. Jakarta: Kementerian Hukum dan Hak Asasi Manusia. 
Jurnal Mangifera Edu, Volume 4, Nomor 2, Januari 2020, Halaman 143-156

Purwandari, D. N. (2017). Pentingnya Kompetensi Pedagogik Guru Dalam Proses Pembelajaran Di Sekolah Dasar. Jurnal pendidikan, 2(3), 197-208.

Purwoko, R. Y. (2017). Analisis Kemampuan Conten Knowledge Mahasiswa Calon Guru Matematika Pada Praktek Pembelajaran Mikro. Jurnal Pendidikan Surya Edukasi (JPSE), 3(1), 55-65.

Hasse, S, et all. (2014). Assessing Teaching and Assessment Competences of Biology Teacher Trainees: Lessons from Item Development. International Journal of Education in Mathematics, Science and Technology, 2(3), 191-205.

Sukaesih, S., Ridlo, S., \& Saptono, S. (2017). Profil Kemampuan Pedagogical Content Knowledge (PCK) Calon Guru Biologi. Jurnal Lembaran Ilmu Kependidikan, 46(1), 68-74.

Susanti, R., Juwaedah, A., \& Lasmawati, E. (2013). Pendapat Dosen Luarbiasa Tentang Kompetensi Sosial Praktik Program Pengalaman Lapangan (PPL) Mahasiswa Prodi Pendidikan Tata Boga. Media Pendidikan, Gizi dan Kuliner, 2(1), 45-50.

Martini, S (2017). Landasan Filsafat Konstruktivisme Dalam Pembelajaran Sains. Jurnal Mangifera edu, 1(2), 35-45.

Susetya, B. (2016). Meningkatkan Kemampuan Guru Dalam Menyusun Silabus RPP Melalui Supervisi Akademik Di SDN Gambiran Yogyakarta. Jurnal Taman Cendikia, 1(2), 134-141.

Theodorus. (2019 Februari 19). Berita Rekrutmen CPNS 2018. Pos-Kupang.com (online). 